\title{
A comparative study of VITEK-2, Double Disc Synergy and Combined Disc Methods for detection of ESBL (Extended Spectrum Beta-Lactamase) production in Escherichia coli and Klebsiella pneumoniae strains
}

\author{
Escherichia colive Klebsiella pneumoniae suşlarında ESBL (Genişletilmiş \\ Spektrum Beta-Laktamaz) üretiminin saptanması için VITEK-2, Çift Disk \\ Sinerjisi ve Kombine Disk Yöntemlerinin karşılaştırmalı bir çalışması
}

\author{
@Mustafa Yılmaz', OÖznur Ak1, ๑Demet Hacıseyitoğlu², @Sevil Alkan³ \\ 'Health Sciences University Evliya Çelebi Training and Research Hospital, Infectious Diseases and Clinical Microbiology, Kütahya, Turkey \\ ${ }^{2}$ Health Sciences University Dr. Lütfi Kırdar Training and Research Hospital, Clinical Microbiology Laboratory, Istanbul, Turkey \\ ${ }^{3}$ Çanakkale Onsekiz Mart University Faculty of Medicine, Department of Infectious Diseases and Clinical Microbiology, Çanakkale, Turkey
}

\begin{abstract}
Aim: In this prospective study we aimed to compare the effectiveness of VITEK-2 (bioMérieux, France) automated system, double disc synergy test (DDST) versus combined disc test (CDT) in detecting the Extended Spectrum Beta-Lactamase (ESBL) positivity in Escherichia coliand Klebsiella pneumoniae strains isolated from various clinical samples.

Material and Method: E. coliand K.pneumoniaestrains inoculated on Mueller Hinton Agar plate. Susceptibility tests were performed with the VITEK 2 (BioMérieux, France) system before. Afterward, EBSL positivity was investigated manually DDST and CDT. Minimal inhibitor concentration (MIC) results of three tests were compared with each other according to the European Committee on Antimicrobial Susceptibility Testing (EUCAST) criteria.

Results: 184 E. coli and K. pneumoniae strains, elevuated. 92.9\% of 98 patients with VITEK 2 positive results were positive with combined disc and DDS method, $100 \%$ of the 86 patients with negative results of VITEK 2 were negative with combined disc and DDST.

Conclusion: VITEK 2 was found to have a sensitivity of $100 \%$, a specificity of $92.4 \%$, a positive predictive value of $92.8 \%$ and a negative predictive value of $100 \%$. VITEK 2 was found to be compatible with validation tests for ESBL positivity.
\end{abstract}

Keywords: Escherichia coli, Klebsiella pneumoniae, VITEK-2, Double Disk Synergy (DDS) Test, Combined disc test, ExtendedSpectrum Beta-Lactamase (ESBL)
Öz

Amaç: Bu prospektif çalışmada, çeşitli klinik örneklerden izole edilen Klebsiella pneumoniae ve Escherichia coli suşlarında Genişletilmiş Spektrum Beta-Laktamaz (ESBL) pozitifliğini saptamada VITEK-2 (bioMérieux, Fransa) otomatize sistem, çift disk sinerji testi (ÇDST) ve kombine disk testinin (KDT) etkinliğini karşılaştırmayı amaçladık.

Gereç ve Yöntem: E. coli ve K. pneumoniae suşları Mueller Hinton Agar plağına inokule edildi. Duyarlılık testleri önce VITEK 2 (BioMérieux, Fransa) sistemi ile değerlendirildi. Sonrasında EBSL pozitifliği manuel olarak ÇDST ve KDT ile araştırıldı. Üç testin minimum inhibitör konsantrasyonu (MIC) sonuçları, Avrupa Antimikrobiyal Duyarlılık Testi (EUCAST) kriterlerine göre birbirleriyle karşılaştırıldı.

Bulgular: 184 E. coli ve K. pneumoniae suşu değerlendirildi. VITEK 2 pozitif sonucu olan 98 hastanın \%92,9'u kombine disk ve DDS yöntemi ile pozitifti, VITEK 2 negatif sonucu olan 86 hastanın \%100'ü kombine disk ve DDST ile negatifti.

Sonuç: VITEK 2'nin \%100 duyarlılık, \%92,4 özgüllük, \%92,8 pozitif öngörü değeri ve \%100 negatif öngörü değerine sahip olduğu bulundu. VITEK 2'nin ESBL pozitifliği için doğrulama testleri ile uyumlu olduğu bulundu.

Anahtar Kelimeler: Escherichia coli, Klebsiella pneumoniae, VITEK-2, Çift Disk Sinerjisi (DDS) Testi, Kombine disk testi, Genişletilmiş Spektrumlu Beta-Laktamaz (ESBL)

Corresponding (illetişim): Mustafa Yılmaz, Health Sciences University Evliya Çelebi Training and Research Hospital, Infectious Diseases and Clinical Microbiology, Kütahya, Turkey

E-mail (E-posta): drmustafayilmaz29@hotmail.com

Received (Geliş Tarihi): 17.06.2021Ａccepted (Kabul Tarihi): 09.10.2021 


\section{INTRODUCTION}

Extended Spectrum Beta-Lactamases (ESBL) were first reported in Germany in 1983, just after the introduction of broad-spectrum beta-lactam antibiotics against Klebsiella pneumoniae species. ${ }^{[1]}$ The most crucial mechanism for developing resistance to beta-lactam antibiotics in gramnegative bacteria is beta-lactamase synthesis. Today, approximately 600 beta-lactamase enzymes have been identified. The most important beta-lactamase enzyme groups are cephalosporinase which is genetically encoded by plasmids, metallo-beta-lactamase and ESBL. ESBLs are enzymes that can cause resistance to penicillin, all cephalosporins except cephamycins (cefoxitin, moxalactam) and aztreonam, be inactivated with beta-lactamase inhibitors such as clavulanic acid, sulbactam or tazobactam, and generate different enzymes as a result of different amino acid changes in TEM and SHV enzymes. ${ }^{[2,3]}$ Plasmids that encode ESBL, also contain genetic material against many antibiotics other than beta-lactams in their genetic structure. As a result, the bacteria that can synthesize ESBL can be simultaneously resistant to fluoroquinolone, tetracycline, chloramphenicol, trimethoprim-sulfamethoxazole, and especially aminoglycosides. ${ }^{[4-6]}$

Today, ESBL screening is recommended for research purposes in infection control and epidemiological studies. Screening and verification tests are used to determine the presence of ESBL. Inhibition diameter is determined by disk diffusion test performed with cefotaxime, ceftriaxone, ceftazidime, cefpodoxime as screening test or the minimum inhibitory concentration (MIC) is determined by the liquid dilution method. If the zone diameters from the test are lower than the limit values specified in international sources for the tested antibiotics, or the MIC values are greater than the limit values, a verification test should be performed. Verification tests consist of phenotypic tests such as combination disk test, double disk synergy test and microdilution test, and genotypic tests such as PCR (polymerase chain reaction). ESBL can be found in various commercial kits and automated systems. ${ }^{[7-9]}$

The aim of this study was to investigate whether there is a difference between the VITEK 2 (BioMérieux, France) fully automated system and double disc synergy (DDST) versus combined disc test (CDT) in detecting the presence of ESBL.

\section{MATERIAL AND METHOD}

In this prospective study, 131 E. coli and 53 K. pneumoniae strains isolated from various clinical samples as an infectious agent between November 2016 and January 2017, were included. Susceptibility tests were performed with the VITEK 2 (BioMérieux, France) system before, and after DDSTs and CDTs were applied to ESBL positive or negative E. coli or $K$. pneumoniae strains. For this test bacterial suspension which prepared in 0.5 McFarland turbidity was inoculated to Mueller Hinton Agar (MHA) plate. E. coli ATCC 25922 used as a positive and negative control group. E. coli and K. pneumoniae strains inoculated on Mueller Hinton Agar plate. Susceptibility tests were performed with the VITEK 2 (BioMérieux, France) system before, and after Minimal inhibitor concentration (MIC) results of three tests were compared with each other according to the European Committee on Antimicrobial Susceptibility Testing (EUCAST) criteria.

a.Double Disc Sinergy Test: After placing an amoxicillinclavulanic acid (AMC) $(20 / 10 \mu \mathrm{g})$ disc in the centre of the petri dish and placing ceftazidime (CAZ) $(30 \mu \mathrm{g})$, ceftriaxone (CRO) $(30 \mu \mathrm{g})$, cefoxitin (FOX) $(30 \mu \mathrm{g})$, cefotaxime (CTX) $(30 \mu \mathrm{g})$ radially at a distance of $25 \mathrm{~mm}$ from AMC's disc circumference, an expansion towards the AMC disk in the inhibition zones around the CAZ, CRO, FOX or CTX discs or the presence of a non-bacterial synergy area in between was evaluated as ESBL production.

b.Combine Disc Test: In this method ceftazidime (CAZ) (30 $\mu \mathrm{g})$, ceftazidime-clavulanic acid (CCA) $(30 / 10 \mu \mathrm{g})$, cefotaxime (CTX) $(30 \mu \mathrm{g})$, cefotaxime-clavulanic acid (CCT) $(30 / 10 \mu \mathrm{g})$ was used. Bacterial suspension which prepared in $0.5 \mathrm{McFarland}$ turbidity was spread with sterile swab to Mueller-Hinton Agar medium. CAZ and CCA discs were placed in the petri dish with $30 \mathrm{~mm}$ between them and same procedure was applied to CTX and CCT disks. Petri dishes was incubated at $35^{\circ} \mathrm{C}$ for 18 hour and results was evaluated according to EUCAST criteria. $5 \mathrm{~mm}$ or difference more than that between cephalosporin disc and cephalosporin -clavulanate disc was evaluated as ESBL production.

Ethical approval: In order to conduct the study, Ethical approval was taken from Clinical Researches Ethics Committee of Dr. Lütfi Kırdar Training and Research Hospital (Date: 29.11.2016, Decision No: 2016/514/96/2). All procedures were carried out in accordance with the ethical rules and the principles of the Declaration of Helsinki.

Statistical analysis: Statistical Packages for the Social Sciences (SPSS) for Windows 22.0 package program was used for statistical analysis.

\section{RESULTS}

In our study, 131 E. coli and 53 K. pneumoniae strains isolated from various clinical samples were evaluated. Of the patients from whom the isolates were obtained, 126 (68.5\%) were female, $58(31.5 \%)$ were male and the age range was 6 months-92 years, the average age was 42 . The most common comorbidities were hypertension (21.2\%), Diabetes Mellitus (DM) (16.3\%) and malignancy (13.6\%)(Table 1). The antibiotics used by the patients in the last three months were questioned in terms of ESBL positivity (Table 2). The distribution of the samples included in the study is as follows; $162(88.0 \%)$ were urine, 9 (4.9\%) were wound, 5 (2.7\%) were trachea and sputum and $3(1.6 \%)$ were tissue culture. The antibiotic susceptibility results of $E$. coli and $K$. pneumoniae strains with VITEK-2 are shown in Table 3. 
In this study, ESBL positivity was detected by VITEK 2, the confirmation tests were performed on these strains with the DDSTs and CDTs to 63 (48.1\%) 131 of E. coli strains and 35 (66\%) 53 of $K$. pneumoniae strains. The verification tests gave positive results methods in 91 (92.9\%) of 98 strains that VITEK 2 gave positive results, 86 (100\%) of 86 strains that VITEK 2 gave negative results were found negative by CDTs and DDS method. DDST and CDTs results were consistent with each other in terms of positivity and negativity. Evaluated only for $E$. coli; the confirmation tests gave positive results in 57 (90.5\%) out of 63 strains that VITEK 2 gave positive results, 68 (100\%) of 68 strains that gave negative results with VITEK 2 were also found negative by combined disc and double disc synergy method. Evaluated only for K. pneumoniae; the confirmation tests gave positive results in $34(97.1 \%)$ out of 35 strains that VITEK 2 gave positive results, 18 (100\%) of 18 strains that gave negative results with VITEK 2 were also found negative by DDSTs and CDTs method.

Thus, when the VITEK 2 results were compared with the validation tests that studied, the sensitivity was $100 \%$, specificity $92.4 \%$, PPD $92.8 \%$, NPD $100 \%$ for all strains. For $E$. coli, sensitivity $100 \%$, specificity $91.9 \%$, PPD $90.5 \%$, NPD 100\%; For K. pneumoniae, the sensitivity $100 \%$, specificity $94.7 \%$, PPD $97.1 \%$ and NPD $100 \%$ was found (Table 4).

\section{DISCUSSION}

The most important mechanics in gram negative bacteria for developing resistance against beta-lactam antibiotics is betalactamase synthesis, and approximately 600 beta-lactamase enzymes have been identified since today. Because enteric bacteria that can synthesize this enzyme can easily transfer these enzymes to other bacteria via plasmids, the number of bacteria that can synthesize this enzyme is increasing day by day. ${ }^{[1-3]}$ Microorganisms that synthesize ESBL, can transfer these enzymes between species and could cause epidemic in hospitals. In bacterial infection that can synthesize ESBL, should be investigated whether the factor causes ESBL due to the insufficiency of many antibiotics in the treatment, prolonged hospitalization stay, increased morbidity and mortality rates, and serious economic losses. ${ }^{[5,6]}$

Various studies have been conducted in the literature on methods that detect ESBL production. ${ }^{[10-2]}$ In a comparative study which done with various automatize systems, DDS test and E-test on 150 enteric bacteria, VITEK 2 (BioMérieux, Fransa), Phoenix Automated Microbiology System (BD Diagnostic Systems, Sparks, MD, ABD), MicroScan WalkAway-96 System (Dade Behring, Inc., West Sacramento, $(\mathrm{A}, \mathrm{ABD}), \mathrm{DDS}$ test and E-test methods for the ESBL detection sensitivity for $E$. coli $(\mathrm{n}=61)$ respectively $81.4 \%, 100 \%, 100 \%$, $97.7 \%, 97.7 \%$, specificity $100 \%, 72.2 \%, 72.2 \%, 100 \%, 94.4 \%$, PPD $100 \%, 89.6 \%, 89.6 \%, 100 \%, 94.4 \%$, NPD 69.2\%, 100\%, $100 \%, 94.7 \%, 97.7 \%$, The ESBL detection sensitivity for $K$. pneumoniae $(\mathrm{n}=29) 95.7 \%, 100 \%, 95.7 \%, 91.3 \%, 100 \%$, and the specificity $83.3 \%, 66.7 \%, 50 \%, 100 \%, 83.3 \%$, PPD $95.7 \%$,
Table 1. Demographic information, factors and underlying diseases

\begin{tabular}{lcc} 
& $\mathbf{n}$ & $\%$ \\
\hline Gender (Female) & $126 / 58$ & 68.5 \\
Isolated bacteria & & \\
E. coli & 131 & 71.2 \\
K. pneumoniae & 53 & 28.8 \\
Underlying diseases & & \\
Hypertension & 39 & 21.2 \\
Diabetes mellitus & 30 & 16.3 \\
Malignancy & 25 & 13.6 \\
Coronary artery disease & 15 & 8.2 \\
Chronic kidney failure & 13 & 7.1 \\
Chronic obstructive pulmonary disease & 9 & 4.9 \\
Cerebrovascular Disease & 2 & 1.1 \\
\hline
\end{tabular}

Table 2. Antibiotics Used by Patients in the Last Three Months

\begin{tabular}{lcccc} 
Antibiotic & Exist & $\mathbf{( \% )}$ & Non-exist & $\mathbf{( \% )}$ \\
\hline Aminopenicillin & 24 & 13 & 160 & 87 \\
Phosphomycine & 20 & 10.9 & 164 & 89.1 \\
$2^{\text {nd }}$ generation cephalosporin & 19 & 10.3 & 165 & 89.7 \\
Fluoroquinolone & 16 & 8.7 & 168 & 91.3 \\
$3^{\text {rd }}$ generation cephalosporin & 11 & 6.0 & 173 & 94.0 \\
Trimethoprim-sulfamethoxazole & 7 & 3.8 & 177 & 96.2 \\
Nitrofurantoin & 3 & 1.6 & 181 & 98.4 \\
$1^{\text {st }}$ generation cephalosporin & 3 & 1.6 & 181 & 98.4 \\
Aminoglycoside & 3 & 1.6 & 181 & 98.4 \\
Other antibiotics & 3 & 1.5 & 181 & 98.5 \\
\hline *Other antibiotics: (tetracycline, clindamycin, fusidic acid) & & &
\end{tabular}

*Other antibiotics: (tetracycline, clindamycin, fusidic acid)

\begin{tabular}{|c|c|c|c|c|}
\hline Antibiotic & Susceptible & (\%) & Resistant & $(\%)$ \\
\hline Ampicilline & 45 & 24.5 & 139 & 75.5 \\
\hline Amoxicilline-clavulanic acid & 90 & 48.9 & 94 & 51.1 \\
\hline Cefuroxime & 81 & 44.0 & 103 & 56.0 \\
\hline Cefuroxime axetil & 81 & 44.0 & 103 & 56.0 \\
\hline Ceftazidime & 86 & 46.7 & 98 & 53.3 \\
\hline Ceftriaxone & 86 & 46.7 & 98 & 53.3 \\
\hline Cefixime & 83 & 45.1 & 101 & 54.9 \\
\hline Piperacillin-tazobactam & 114 & 62.0 & 70 & 38.0 \\
\hline Imipeneme & 176 & 95.7 & 8 & 4.3 \\
\hline Meropeneme & 180 & 97.8 & 4 & 2.2 \\
\hline Ertapenem & 178 & 96.7 & 6 & 3.3 \\
\hline Amikacin & 139 & 75.5 & 45 & 24.5 \\
\hline Gentamicin & 139 & 75.5 & 45 & 24.5 \\
\hline Ciprofloxacin & 118 & 64.1 & 66 & 35.9 \\
\hline Trimethoprim-sulfamethoxazole & 116 & 63.0 & 68 & 37.0 \\
\hline Tigecycline $^{1}$ & 13 & 7.1 & 1 & 0.5 \\
\hline Nitrofurantoin ${ }^{2}$ & 146 & 79.3 & 18 & 9.8 \\
\hline Phosphomycine ${ }^{2}$ & 150 & 81.5 & 14 & 7.6 \\
\hline
\end{tabular}

Table 4. Comparison of VITEK 2 and verification tests for $E$. coli ve $K$. pneumoniae strains

\begin{tabular}{lccccc} 
Test VITEK 2 & $\mathbf{n}$ & $\begin{array}{c}\text { Susceptibility } \\
\text { \% }\end{array}$ & $\begin{array}{c}\text { Specificity } \\
\%\end{array}$ & $\begin{array}{c}\text { PPD } \\
\%\end{array}$ & $\begin{array}{c}\text { NPD } \\
\%\end{array}$ \\
\hline All strains & 184 & 100 & 92.4 & 92.8 & 100 \\
E. coli & 131 & 100 & 91.9 & 90.5 & 100 \\
K. pneumoniae & 53 & 100 & 94.7 & 97.1 & 100 \\
\hline
\end{tabular}

PPD: positive predictive value, NPD: negative predictive value 
92\%, 88\%, 100\%, 95.8\%, NPD 83.3\%, 100\%, 75\%, 75\%, 100\%, The ESBL detection sensitivity for E. coli, K. oxytoca ve $K$. pneumoniae $(\mathrm{n}=104) 84.5 \%, 100 \%, 98.6 \%, 94.4 \%, 98.6 \%$, and the specificity $93.9 \%, 51.5 \%, 51.5 \%, 97 \%, 72.7 \%$, PPD $96.8 \%$, $81.6 \%, 81.4 \%$, 98.5\%, 88.6\%, NPD 73.8\%, 100\%, 94.4\%, $88.9 \%, 96.0$ was found when when molecular methods were taken as a reference. ${ }^{[10]}$ Fincancl et al. ${ }^{[1]}$ was found screen test that based on zone diameter measurements is significantly sensitive compared to DDS and E-test methods for the ESBL detection sensitivity, similarly Oztürk et al. ${ }^{[12]}$ was found screen test that based on zone diameter measurements is concordant as E-test and more efficient than DDS. There are also studies reporting that there is no difference between DDST test and E-test methods in detecting the presence of ESBL. For example, Yavuz et al. ${ }^{[13]}$ compared the ESBL production in Enterobacteriaceae strains with the DDS test and E-test methods and reported that there was no significant difference between the methods. Yurtman et al. ${ }^{[14]}$ and Akçam et al. ${ }^{[15]}$ did not detect a difference between the DDST test and E-test methods. Genç et al.16 in a study that compared VITEK-2 and DDS which investigated the presence of ESBL for $95 \mathrm{E}$. coli and $61 \mathrm{~K}$. pneumoniae strains and reported that VITEK 2 sensitivity was 93.3\%, specificity $81.8 \%$, false-positivity ratio $18.1 \%$, false-negativity ratio $6.6 \%$ and positivity ratio $86.4 \%$.

In a study which conducted with 117 enteric bacteria that ESBL positivity was determined by combination disk diffusion test, $91 \%$ of the strains with VITEK-2 and $97 \%$ of the strains were found to be ESBL positive with the DDS test, although VITEK 2 could give false negative results It is stated that it can be used routinely in laboratories. ${ }^{[17]}$

Another study which conducted with $94 \mathrm{ESBL}$ positive and 71 ESBL negative enteric bacteria that were studied with molecular methods, VITEK 2 sensitivity 91.5\%, specificity $100 \%$, DDS test sensitivity $97.9 \%$, specificity $97.2 \%$, combined disc test sensitivity $93.6 \%$, specificity $100 \%$ was detected on all strains. ${ }^{[17]}$ Focusing only $E$. coli $(n=79)$, VITEK 2 sensitivity $89.8 \%$, specificity $100 \%$, DDS test sensitivity $98 \%$, specificity $100 \%$, combined disc test sensitivity $89.8 \%$, specificity $100 \%$ was detected. Focusing only $K$. pneumoniae $(n=23)$, VITEK 2 sensitivity $95.7 \%$, specificity $100 \%$, DDS test sensitivity $95.5 \%$, specificity $100 \%$, combined disc test sensitivity $95.5 \%$, specificity $100 \%$ was detected. ${ }^{[18]}$

Mehli et al. ${ }^{[10]}$ was found in their study conducted with 321 enteric bacteria, when DDS test and VITEK 2 was compared in ESBL detection sensitivity and specificity was respectively detected as $100 \%, 94.1 \%$. In another study which conducted with 1123 enteric bacteria with molecular methods as a reference, VITEK-2'nin sensitivity $98.1 \%$, specificity $99.7 \%$, PPD 99.3\%, NPD 99.3\% was detected, for E. coli $(n=534)$ sensitivity $98.1 \%$, specificity $99.5 \%$, PPD 98.1\%, NPD 99.5\%, for $K$. pneumoniae $(n=193)$ sensitivity $97.7 \%$, specificity 100\%, PPD 100\%, NPD 98.1\% was detected and VITEK 2 automatize system can be used rountinely in laboratories for ESBL detection. ${ }^{[19]}$ Kacmaz et al. ${ }^{[20]}$ reported that in some cases where the reliability of the DSS test is decreased (for example, accompanied by different resistance mechanisms such as the production of carbapenemases such as high-level Amp C beta lactamase, metallo beta lactamase and $K$. pneumoniae beta lactamase, excretion mechanisms and decreased permeability with ESBL) It may mask the presence of ESBL and also that the bacteria which resistant to clavulanic acid cannot be evaluated with the DDS test.

Singh et al. ${ }^{[21]}$ compared the 57 ESBL positive strains with six methods. Between these methods, concordance was found with combined disk test and 100\% MIC value. VITEK 2 sensitivity $91.8 \%$ specificity $97.24 \%$, PPD 93.3\% was found in all strains. The highest sensitivity and specificity have been demonstrated with combined disc (93.44\%) and double disc synergy (100\%) techniques, respectively. They reported that VITEK-2 has an acceptable capacity to detect ESBL strains compared to traditional phenotypic methods. ${ }^{[21]}$ ChromID ESBL agar (BioMerieux, France) that developed in recent years, is a chromogenic selective broth that developed to identify ESBL positive Enterobacteriaceae strains earlier than other methods used. The sensitivity and specificity of this broth in detecting ESBL-producing microorganisms were reported as $97 \%$ and $92.9 \%$ respectively, by Alıskan et al. ${ }^{[22]}$ from our country.

In our study when we compared VITEK 2 Automatize System's results with DDS and Combined Disc Methods which are ESBL verification tests, sensitivity 100\%, specificity 92.4\%, PPD $92.8 \%$, NPD $100 \%$ was found in all strains.

\section{CONCLUSION}

ESBL-positivity is an important problem of resistance in Gramnegative bacteria, one of the most important risk factors is antibiotic use. Therefore, attention should be paid to the use of appropriate antibiotics in the appropriate indication. In addition, it was found that the VITEK 2 automated system in laboratories was compatible with confirmation tests in detecting ESBL positivity during the decision-making process in the selection of antibiotics that play a role in the treatment of these infections.

\section{ETHICAL DECLARATIONS}

Ethics Committee Approval: Ethical approval was taken from Clinical Researches Ethics Committee of Dr. Lütfi Kırdar Training and Research Hospital (Date: 29.11.2016, Decision No: 2016/514/96/2).

Informed Consent: All patients signed the free and informed consent form.

Referee Evaluation Process: Externally peer-reviewed.

Conflict of Interest Statement: The authors have no conflicts of interest to declare.

Financial Disclosure: The authors declared that this study has received no financial support. 
Author Contributions: MY, ÖA, DH: design, execution, and analysis; SA: editing, writing, execution. All authors: Approved the final version. This study is corresponding author's thesis study.

\section{REFERENCES}

1. Forbes $A$, Sahm F, Weissfeld S. Principles of antimicrobial action and resistance, In:Fabiano K, Lester S, Wurm E(eds), Bailey \& Scott's Diagnostic Microbiology. 2003,11thed. St. Louis. CV Mosby Co, Missouri. p:214-220.

2. Livermore DM.Defining an extended-spectrum beta-lactamase. Clin Microbiol Infect. 2008;14(1):3-10.

3. Livermore DM. Beta-lactamases in laboratory and clinical resistance. Clin Microbiol Rev. 1995;8(4):557-84.

4. Albertini M, Benoit C, Berardi L. Surveillance of methicillin-resistant Staphylococcus aureus (MRSA) and Enterobacteriaceae producing extended spectrum beta-lactamase (ESBL) in Northern France:a five-year multicentre incidence study. J Hosp Infect. 2002;52(2):107-13.

5. Kang $\mathrm{C}$, Kim SH, Park WB, et al. Bloodstream infections due to extended spectrum beta-lactamases producing $E$. coli and $K$. pneumoniae:Risk factors for treatment outcome with special emphasis on antimicrobial. Antimicrobial Agents Chemother. 2004;48(12):4574-81.

6. Ramphal R, Ambrose PG. Extended spectrum beta-lactamases and clinical outcomes:Current data. Clin Inf Dis. 2006;42 Suppl 4:164-72.

7. Jorgensen $\mathrm{JH}$, Ferraro MJ. Antimicrobial susceptibility testing:special needs for fastidious organisms and difficult-to-detect resistance mechanisms. Clin Infect Dis. 2000;30(5):799-808.

8. Clinical and Laboratory Standards Institute. Performance Standarts for Antimicrobial Susceptibility Testing. 24th Informational Supplement. CLSI Document M100-S24, CLSI, Wayne, PA, 2014.

9. Mehli M, Zer Y, Gayyurhan E. Çeşitli klinik örneklerden izole edilen Enterobacteriaceae suşlarında GSBL oluşturmanın ÇDST ve VITEK 2 yöntemleri ile araştırılması. ANKEM Derg. 2007;21(3):71-5.

10. Fincancı M, Ulutürk R, Eren $G$, et al. Klebsiella pneumoniae, Klebsiella oxytoca ve Escherichia coli kökenlerinde genişletilmiş spektrumlu beta laktamazların araştııımasında kullanılan çeşitli yöntemlerin karşılaştırılması. İnfeksiyon Derg. 2003;17(1):55-60.

11. Öztürk CE, Kaya DA, Yücel M, et al. Genişlemiş Spektrumlu Beta-Laktamaz Tespitinde Kullanılan Bazı Fenotipik Testlerin Karşılaştırılması. ANKEM Derg. 2010;24(3):111-6.

12. Yavuz MT, Ersan G, Süvarierel M. Enterobacteriaceae kökenlerinde genişlemiş spektrumlu beta-laktamaz üretiminin iki farklı yöntemle araştırılması, Düzce Tıp Fak Derg. 2005;2:10-3.

13. Yurtman AN, Hoşgör-Limoncu M, Ermertcan ş, et al. Genişlemiş spektrumlu beta-laktamazların saptanmasında fenotipik yöntemlerin karşılaştırılması. İnfeksiyon Derg. 2009;23(1):5-8.

14. Akçam FZ, Gönen I, Kaya O, et al. Hastane infeksiyonu etkeni çeşitli Gramnegatif bakterilerde genişlemiş spektrumlu beta-laktamaz yapımının iki yöntemle araştııılması. Klimik Derg. 2004;17(1):47-9.

15. Genç S, Dündar D. Escherichia coli ve Klebsiella pneumoniae Suşlarında GSBL Üretiminin Saptanmasında VITEK- 2 Otomatize Sistemi ile Çift Disk Sinerji Testinin Karşılaştırılması. Türk Mikrobiyol Cem Derg. 2015;45(1):3640.

16. Ece G. Comparison of conventional method and automatized vitek system in the detection of extended spectrum beta-lactamase in Escherichia coli and Klebsiella pneumoniae isolates. Afr J Microbiol Res. 2013;7(32):409195.

17. Robin F, Delmas J, Schweitzer C, et al. Evaluation of the Vitek-2 extended-spectrum $\beta$-lactamase test against non-duplicate strains of Enterobacteriaceae producing a broad diversity of well-characte-rised $\beta$-lactamases . Clin Microbiol Infect. 2008;14(2):148-54.

18. Spanu T, Sanguinetti M, Tumbarello M, et al. Evaluation of the new VITEK 2 extended-spectrum beta-lactamase (ESBL) test for rapid detection of ESBL production in Enterobacteriaceae isolates. J Clin Microbiol. 2006;44(9):3257-62.
19. Kaçmaz B, Ece G. Genişlemiş spektrumlu betalaktamaz saptanmasında ikinci, üçüncü ve dördüncü kuşak sefalosporinlerin çift disk sinerji testinde kullanılması ve sefoksitin duyarlıı̆ı. ANKEM Derg. 2010;24(2):61-4.

20. Singh RM, Singh HL. Comparative evaluation of six phenotypic methods for detecting extended-spectrum beta-lactamase-producing Enterobacteriaceae. J Infect Dev .Ctries 2014;8(4):408-15.

21. Alışkan HE, Çolakoğlu ş, Turunç T, Demiroğlu YZ. GSBL Pozitif Enterobacteriaceae ve Vankomisine Dirençli Enterokokların İdrar Kültürlerinden Erken Tespitinde ChromID ESBL Agarın Değerlendirilmesi. Mikrobiyol Bul. 2012;46(1):17-25. 